\title{
Quadrants of invention: Individual patent applications as unutilized resource of innovative capacity
}

\author{
Irina Ervits
}

\begin{tabular}{|c|c|}
\hline \multicolumn{2}{|r|}{ A B S T R A C T } \\
\hline \multicolumn{2}{|c|}{$\begin{array}{l}\text { Objective: This paper emphasizes the importance of isolating individual invention from } \\
\text { organizational inventors such as private companies or universities. It is an explorative } \\
\text { study of the cross-county levels of individual patenting as an indicator of innovative } \\
\text { capacity. Innovative capacity at the national level is linked to economic development. } \\
\text { Thus, we investigate the relationship between different types of patent applications } \\
\text { and GDP per capita in a sample of developed and developing economies. }\end{array}$} \\
\hline \multicolumn{2}{|c|}{$\begin{array}{l}\text { Research Design \& Methods: We screened } 600,000 \text { Patent Cooperation Treaty (PCT) } \\
\text { applications for three years (2013-2015) using a unique selection procedure able to } \\
\text { separate different types of filings. }\end{array}$} \\
\hline \multicolumn{2}{|c|}{$\begin{array}{l}\text { Findings: Countries with higher levels of individual patenting tend to have lower levels } \\
\text { of economic development. Economic progress is driven by corporate or other forms of } \\
\text { organizational inventors and their inventions have a better chance of transitioning into } \\
\text { innovation. At the macro level, individual patenting vis-à-vis patents filed by organiza- } \\
\text { tions reflects unutilized innovative potential rather than innovative output. }\end{array}$} \\
\hline \multicolumn{2}{|c|}{$\begin{array}{l}\text { Contribution \& Value Added: For the first time we demonstrate that high levels of in- } \\
\text { dividual patenting are more characteristic of developing rather than developed econo- } \\
\text { mies. The percentage of individual patent applications is an important indicator of na- } \\
\text { tional innovative capacity. }\end{array}$} \\
\hline icle type: & \\
\hline Keywords: & \\
\hline & \\
\hline & \\
\hline
\end{tabular}

\section{Suggested citation:}

Ervits, I. (2020). Quadrants of invention: Individual patent applications as unutilized resource of innovative capacity. International Entrepreneurship Review (previously published as International Entrepreneurship / Przedsiębiorczość Międzynarodowa), 6(1), 7-27. https://doi.org/10.15678/IER.2020.0601.01 


\section{INTRODUCTION}

This paper uses an innovative selection procedure to isolate individual patent applications - applications filed by individuals rather than organizations - in the World Intellectual Property Organization (WIPO) patent database. We looked at over 600,000 internationally-oriented Patent Cooperation Treaty (PCT) applications for three years (2013-2015). This is the first time when PCT statistics are used for country-level comparisons with regard to individual patent data. We take a new approach to patent data analysis by looking at the relationship between different groups of patent applications and economic output. The link between individual patenting and GDP is, of course, not direct, since there are several macro, meso and micro conditions in between that determine to what extent different categories of applications generate economic output. The micro prerequisites include individual characteristics of an inventor indicating her ability to commercially realize her invention. Meso- and macro-level prerequisites concern the environmental circumstances, including the quality of institutions or the availability of a support network, which determine the successful realization of an invention and its transformation into an innovative product, process or any other form of output.

Analyzing the cases of great inventions in the nineteenth and the beginning of the twentieth centuries, Jewkes et al. (1958) stated that "the industrial laboratory does not appear to be a particularly favorable environment for inducing invention" (Jewkes et al., 1958, p. 132). Jewkes et al. (1958) believed that it is individual creativity, intuition and thirst for knowledge that drive technological progress, and, thus, they make a case against the institutionalization of invention. The socio-economic environment within which invention takes place, however, has changed dramatically since the beginning of the twentieth century. As Khan and Sokoloff (2004) note, circumstances changed as technology evolved and the world industrialized. As such, formal training in science became increasingly important for making contributions to technological development, and the cost of pursuing inventions rose (Khan and Sokoloff, 2004) - in other words, the act of lonely invention transitioned into a corporate lab. Today where invention takes place or who initiates it, an unaffiliated inventor or an inventor working at a university or a firm, might be symptomatic of its economic utility. Admittedly there is a growing need in the innovation system and ecosystem literature to pay more attention to the nature of actors, public and private organizations, involved in innovation process (Mazzucato, 2015; 2018). This paper stresses the importance of understanding the economic effect of patent applications filed by individuals.

Patenting by firms has been naturally prioritized in business studies and economics, but recently university patents have attracted more attention in terms of historical developments (Czarnitzki et al., 2011; Mowery \& Sampat, 2001), or their economic impact (Fabrizio, 2007), or co-invention networks connecting universities, research institutes and firms (Almeida et al., 2011; Perri et al., 2017;). Individual patenting activity has received relatively little attention with the notable exceptions of Amesse et al. (1991), Braunerhjelm and Svensson (2010), Dahlin et al. (2004), Singh and Fleming (2010), Weick and Eakin (2005). This paper stresses the importance of isolating individuals as patenting actors vis-à-vis other types of inventors and tracing their economic effect on the macro level, which, to our knowledge, has not been done before. 
When counts of patents are being used as an indicator of innovative output, the question emerges whether individual filings are comparable to the commercialization or diffusion potential of company applications or filings by other types of inventors. We suggest using the percentage of individual patent applications vis-à-vis other types of filings as an important indicator of national innovative capacity or, to be precise, a lack thereof. The reason to question the economic or technological utility of individual patents is the conceptual and practical difference between invention and innovation (Fagerberg, 2013). Invention, an act of identifying a novel idea and may be materializing it in the form of a patent, is the initial stage of the innovation process. The consequent innovation/commercialization stage is vital for extracting economic value from good ideas. While the role of an individual inventor in conceptualizing this new idea is important, her contribution to its practical realization is unclear. Thus, there is a higher chance that unaffiliated patent applications might not reach the stage of commercialization or become innovation compared to their corporate counterparts. This is not to say that individual patent filings are necessarily inferior in technological potential or not novel, but simply because the entrepreneurial impetus, organizational support or necessary infrastructure that a firm offers might be lacking in the case of a "lonely" inventor. Furthermore, individual patent applications are especially sensitive to the availability of macro and meso prerequisites, which are lacking in developing economies or emerging markets. If, for example, at macro level, institutional infrastructure creates a discouraging business climate for an act of entrepreneurship or there is little venture capital available, then fewer inventions are turned into innovations and then commercialized.

\section{Research Goals}

This paper has exploratory goals to understand the dynamics of individual patenting across countries. We use international patent applications ${ }^{1}$ filed through the Patent Cooperation Treaty (PCT) of the World Intellectual Property Organization (WIPO) patent database as a measurement of inventive activity on the macro level. The basis of our analysis is the ability to separate individual patent applications from organizational patents in the sample of over 600,000 PCT applications for the years 2013, 2014 and 2015. By "organizational patent application" we mean applications filed by companies, government agencies, research institutes and universities. Invention can turn into innovation provided that some micro, meso and macro environmental conditions are met. And then innovation translates into economic development. National innovative capacity and economic development are closely interlinked. We look at the relationship between different types of patent applications (reflecting, we believe, different potential for commercialization) and GDP per capita in a sample of developed and developing economies.

\footnotetext{
${ }^{1}$ It should be noted that there is a difference between a patent application and a granted patent. Under the PCT system, national authorities of countries where property rights are sought grant these rights. WIPO publishes patent applications after an International Searching Authority (ISA) screens the application with regard to its novelty, inventiveness and industrial applicability, following which it produces a written opinion (or 18 months after the application date) (WIPO, 2015a). For the purposes of this paper, however, the most important characteristic of these applications is not their quality with regard to patentability; this paper is concerned with sources of patenting activity at the national level.
} 


\section{LITERATURE REVIEW}

\section{Invention and Innovation}

Pinchot (1985) in his book dedicated to the phenomenon of "intrapreneurship" or an act of innovative entrepreneurship within the confines of a corporation or any type of organization, including government agencies, summarized the distinction between invention and innovation.

Innovation does not mean invention. Invention is the act of genius in creating a new concept for a potentially useful new device or service. In innovation, that is just the beginning. When the invention is done, the second half of innovation begins, turning the new idea into a business success. This second step may be called implementation, commercial development, new venture creation, or any of a host of other names; it is as essential to innovation as thinking of the idea in the first place (Pinchot, 1985, p. 11).

Invention is, therefore, the first stage of the innovation process. Similarly, in King et al. (1994, p. 140), innovation is defined as a process that involves moving through three overlapping stages, invention, innovation and diffusion. The division into separate stages goes back to Schumpeter, who differentiated between the processes of invention and innovation. In keeping with his definition, as recounted in Dosi and Nelson (2013), invention concerns the original development of some novel product or process, while innovation entails its application and economic exploitation. Diffusion implies its usage by others, including consumers (Dosi \& Nelson, 2013). According to Dosi and Nelson (2013, p. 30), invention is suggestive of "unexploited potential for technological progress," while "innovation and diffusion hint at the economically motivated efforts aimed at the incorporation of technological advances into economically exploitable products and processes." Even though The Oslo Manual, the manual for conducting surveys on the innovative behavior of firms, by the Organization for Economic Co-operation and Development (OECD), does not stress the division into different phases of the innovation process ${ }^{2}$ it nevertheless emphasizes the practical side of innovation (supposedly vis-à-vis invention), which involves the "utilization of new knowledge or a new use of existing knowledge" (OECD \& Eurostat, 2005, p. 35).

The distinction between invention and innovation goes back to Schumpeter who has consistently stressed the distinction between an "inventor" and an "entrepreneur" or innovator (Ruttan, 1959). According to Schumpeter (1947, p. 152), the inventor produces ideas and the entrepreneur "gets things done," which may or may not imply a new scientific contribution. In addition, "getting things done" is a critical part of capitalist reality (Schumpeter, 1947, p. 152). Invention and innovation are produced by different sets of incentives and social processes. Innovation is closely linked to the act of entrepreneurship, it is a driver of economic change in a capitalistic society and a reflector of business behavior (Schumpeter, 1939). He viewed entrepreneurial activity as a third factor of production, next to labor and land (Hagedoorn, 1996), which is in line with the argument made later

\footnotetext{
${ }^{2}$ After all, The Oslo Manual (OECD \& Eurostat, 2005) focuses on innovation at the firm level, so the invention stage is implied and the distinction between the two is of little relevance to the authors of the manual or its potential users.
} 
by Romer $(1986,1990)$ about the endogenous role of innovation in productivity and economic growth. Schumpeter introduced the concept of "new combinations" as the essence of innovation, and they "refer to the introduction of a new product or a new quality of a product, a new method of production, a new market, a new source of supply of raw materials or half-manufactured goods, and finally implementing the new organization of any industry" (Hagedoorn, 1996, pp. 885-886).

The context in which innovation takes place is important. Schumpeter's comments on the nature of innovation inspired the literature on technological regimes, which explores the industrial contexts of innovation, differentiating between the Schumpeter Mark I and Mark II patterns of innovation, as proposed in Dosi et al. (1995). Schumpeter Mark I industries are characterized by dynamic environments of "creative destruction", where innovations are generated by small entrepreneurial firms. Schumpeter Mark II industries are regarded as stable environments, where innovations are generated by large established firms (Malebra \& Orsenigo, 1995, 1997). The term "Schumpeter Mark I" refers to the so-called early view of innovation advanced by Schumpeter in The Theory of Economic Development (1911), in that innovation is driven mainly by the entrepreneur, and "Schumpeter Mark II" - to his later conclusion in Capitalism, Socialism and Democracy (1942), namely that innovation can be exercised within large corporations or concentrated industry clusters (Fontana et al., 2012). This distinction lies at the heart of the well-known "Schumpeterian hypothesis" - the relationship between industrial concentration/firm size and innovation (Marsili \& Verspagen, 2002), which has been empirically tested. Castellacci (2007), for instance, finds that Schumpeter Mark II sectors are characterized by higher rates of productivity. Granstrand and Alaenge (1995) conclude that large corporations (Schumpeter Mark II) have dominated in introducing innovations in almost all industrial sectors and in all observed periods in Sweden. This argument brings us back to the goals of this project to explore the economic effects of different types of patent applications, which serve as proxies of invention and reflect different organizational contexts. Specifically we are interested in the effects of individual patenting vis-à-vis other types of patent applicants.

\section{Economic Effects of Individual Patents}

For Schumpeter (1939, 1942, 1947), the functions of an inventor and innovator/entrepreneur, and the two corresponding processes, were quite distinct. An inventor invents things, while an entrepreneur (who can be an inventor or not) has the specific social and economic function of turning inventions into innovation, which ultimately drives economic growth (Schumpeter, 1939). The distinction between invention and innovation, inspired by Schumpeter, is important, because it goes to the heart of the debate about the economic benefits of individual patents. Trajtenberg (2002) questions the ability of individual or "unassigned" patents to contribute to the national economy. Singh and Fleming (2010), Braunerhjelm and Svensson (2010) and Dahlin et al. (2004) assessed the economic value of patents generated by individuals without organizational backing and came to similar conclusions. These findings confirm the assertions that individual inventors might lack the organizational support and profit-oriented drive of an entrepreneurial entity, be it a small start-up or a corporation. Without the institutional backing of a larger company being able to attract venture capital or contributing its own funds to $R \& D$ (or even a government agency financing technological development for public use), 
the fate of invention might not find economic realization, especially today, when innovation is associated strongly with high capital investments.

The private sector is granted a special role in the market economy to drive technological change (OECD \& Eurostat, 1996). Private enterprises turn new ideas into functional forms and commercialize them, therefore fulfilling the entrepreneurial function, according to Schumpeter. In a broader, evolutionary sense, Schumpeter made an argument that "the creative response of entrepreneurs and entrepreneurial innovation are the primary determinants of economic change," and without this social and economic function capitalism would stagnate (Frank, 1998, p. 513). In a later period, the image of a heroic individual entrepreneur in Schumpeter's writings was replaced by the postulation that large corporate $R \& D$ laboratories would undertake an entrepreneurial function in the process of innovation - the inspiration for Schumpeter Mark II innovation pattern. Ultimately, the role of a lonely inventor, as separated from the function of an entrepreneur, plays a marginal role in economic development (even though it might have meaningful social or cultural implications or inspire an innovation effort performed by somebody else).

Thus, the chances of successful innovation are determined by different forms of organizational support, a private firm (large or small), especially in free market economies, or government agencies and state-owned enterprises or universities. Large corporations usually have more resources to dedicate to innovative activities, while small business relies more on venture capital. Even though government-funded research institutes and universities might be focusing more on fundamental rather than applied research, they also enjoy government funding and extensive connections to the private sector, which makes the development and application-driven conceptualization of new technology more feasible (and its commercialization) than in a scenario of a single inventor. Therefore, this research endeavour is driven by an assumption that even at the macro level we should be able to see different economic effects of patenting depending on who files for patent protection. Economically advanced countries should have higher percentage of private sector filings. While the patenting record of less developed economies might be skewed more toward individual applications implying on one hand, the creative potential of its population but, on the other hand, fewer prospects of commercial realization of these patents. If that is the case, then the proportion of individual patenting must be treated as an important indicator of national innovative capacity and should be properly accounted for in various innovation rankings and indices.

\section{MATERIAL AND METHODS}

This paper looks at the relationship between different types of patent applications and GDP per capita in a sample of developed and developing economies. The basis of our analysis is the unique categorization procedure of separating individual patent applications from organizational patents in the sample of over 600,000 PCT applications for the years 2013, 2014 and 2015. This is the first time when PCT statistics are used for country-level comparisons with regard to individual patent data. 


\section{Data Sources}

This paper follows a long tradition of using patent statistics as a measure of inventive activity (Comanor \& Scherer, 1969; Griliches, 1990; Griliches \& Schmookler, 1963; Mueller, 1966; Scherer, 1965; Schmookler, 1966; Schmookler \& Brownlee, 1962). ${ }^{3}$ A patent satisfies the minimum requirement of invention with regard to its practical orientation and novelty being acknowledged by the national patent office (Griliches, 1990). Patents have been used as a proxy of innovation, for instance to investigate the link between innovation and national competitiveness (Pavitt \& Soete, 1980; Scherer, 1992; Sood \& DuBois, 1995) or as an output indicator of corporate R\&D activities (Aitken \& Harrison 1994; Cantwell \& Janne, 1999; Cantwell \& Piscitello, 2005; Frost, 2001; Zanfei, 2000). The Oslo Manual treats patents as a "method for maintaining and increasing competitiveness of innovations" (OECD and Eurostat, 1996, p. 58). The conversation about the use of patent data as a measure of innovation, as well as methodological implications of this data source, culminated in Jaffe and Trajtenberg (2002). Today, it is often assumed that patent data can be utilized as one of the measures of innovation (Bradford University School of Management [BUSM], 2009) alongside expenditure on research and development (R\&D), scientific publications, personnel engaged in $R \& D$, numbers of science graduates per capita or high-technology exports.

WIPO is a United Nations (UN) agency that monitors the global system of intellectual property (IP) protection. The choice of PCT applications is dictated by four reasons. First, the PCT application procedure is standardized across all now 152 member countries, with the objective of enabling simultaneous patenting in multiple jurisdictions instead of filing a separate application in each country. So, a PCT application is an internationally-oriented application. Standardized applications are filed with a national (country of residence of the applicant) or regional patent office or directly with WIPO (WIPO, 2015a). The standardization of the PCT procedure warrants quality homogenization and consistency, as the same formal requirements apply to all applicants regardless of nationality.

Secondly, applicants pay a standard set of international fees to initiate their application, and WIPO provides fee reductions to applicants from developing countries (WIPO, 2015a). At a later stage of the application process, the so-called national stage, some national or regional patent-granting authorities also provide fee reductions to individuals, universities, not-for-profit research institutes and small- and medium-sized enterprises (SMEs) (WIPO, 2015a, 2015b). This system of fee reductions has an equalizing effect and encourages a diverse range of applicants to apply. Despite the fact that large multinational corporations like Huawei, Panasonic or Samsung have been consistently top PCT applicants (as per WIPO Statistics Database ${ }^{4}$ ), filing thousands of applications annually, the PCT procedure is deemed to be especially attractive to internationalizing SMEs (WIPO, 2015a, 2015b). Thus, fee reductions for non-corporate inventors diversify the PCT application pool and ensure a high level of individual filings across the

\footnotetext{
${ }^{3}$ The limitations of patent data as a measure of invention are well known. Not all novel ideas are patentable, as the quality of patent applications differs significantly. Alternative indicators like R\&D expenditure or scientific publications have been utilized. Surveys at the firm level also serve as a source of data on innovative effort. ${ }^{4}$ Please see details at PATENTSCOPE, https://patentscope.wipo.int/search/de/search.jsf. Accessed April 2018.
} 
board, which might not be the case in some national IP jurisdictions, where corporations dominate.

The third reason for choosing PCT is the practical matter of data availability, at least for the years 2013, 2014, and 2015. The WIPO patent database, PATENTSCOPE, provides an opportunity, which was essential for this paper, to download lists of all PCT applications published in a particular year. The lists provide detailed descriptions of patent applications, including information about the applying body and where the application was filed (based on the two-letter country code assigned to the application). The final reason is a purely intuitive assumption that internationally-oriented PCT applications imply a certain level of confidence by an applicant about the prospects of her idea abroad, which in turn might represent an indirect measure of quality. The intention of internationalization imposes quality expectations that might be more demanding than with domestic patenting. For example, for Russian inventors it is easier to obtain a domestic patent rather than an international alternative, because domestic requirements are less stringent than requirements abroad (Gianella \& Tompson, 2007).

\section{Categorization Procedures}

This paper looked at all PCT applications published on PATENTSCOPE in 2013, 2014 and 2015. PATENTSCOPE assigns a two-letter code to an application based on where the patent was filed. Applications with the two-letter code "EP" stand for those filed with the European Patent Organization (EPO), ${ }^{5}$ and the code "IB" corresponds to patents applied for through the International Bureau of WIPO (WIPO, 2016). Since applications in the database can be at different processing stages, all duplicate application numbers were removed to distil the list to the 299,530 applications under investigation. ${ }^{6}$ PCT applications go through the stages of assessment, amendments, corrections, etc. with each additional change being recorded and published. ${ }^{7}$

On PATENTSCOPE, a patent application mentions three categories of individuals or organizations: applicants, inventors and agents. Applicants file patent applications, and there can be more than one applicant. When a patent is granted, applicants retain IP rights for the invention (WIPO, 2015c). Inventors are those who conceived and conceptualized the invention described in the patent application (sometimes an applicant and an inventor are the same person). Agents provide legal and technical support to applicants, but this paper is concerned only with applicants. When an application was filed

\footnotetext{
${ }^{5}$ Currently, there are 38 member states of European Patent Organization (EPO), EU members, Albania, Croatia, Macedonia, Iceland, Liechtenstein, Monaco, Norway, San Marino, Serbia, Switzerland and Turkey. The list is available here: https://www.epo.org/about-us/foundation/member-states.html. In many cases, the country where the application was filed coincides with the country of residence of the first-named applicant, for example when a French company applies via the domestic patent office. However, many European companies apply through EPO. Using the two-letter code as a national identification criterion has, however, its limitations. It does not help separate domestic applications from foreign country subsidiaries. An applying company might be a subsidiary or a separate division of a larger company located in a different country. Internationalization of R\&D activities has become widespread practice especially among large multinational corporations (MNEs). As Griliches (1990) notes, firm diversification and internationalization strategies, as well as mergers, create technical problems in using patent data (p. 1668).

6 96,197 filings in 2013, 103,018 - in 2014, 100,315 - in 2015.

${ }^{7}$ Please see details at the WIPO website, http://www.wipo.int/patentscope/en/data/kind_codes.html. Accessed in March 2018.
} 
by an individual or a group of individuals (as applicants), it was classified as an "individual application." When an application was filed by a company, it was correspondingly termed a "company application." In the same manner, applications from government agencies, research centers and universities were grouped into a separate category. We used the regular expression technique when an algorithm written in the Perl script language grouped 299,530 PCT applications from 92 countries $^{8}$ for three years (2013, 2014, and 2015) into three categories, 1. Companies; 2. Government, universities, and research centers; 3 . Individuals.

The selection procedure was based on keywords in Table 1. In the process of scanning for errors we also identified additional key words, so the key word list grew organically. For example, company names like "Progress, Inc." would be placed in the "company applications" folder. The selection process is essentially a process of extraction. First, based on specific keywords, the group of government and academic applicants was isolated. Then, from the remaining filings the companies were removed and formed a separate group. The remaining filings contained "individual applications". Then, we scanned manually the group of individual applications and removed any company or government or academic application and placed them into the appropriate files. Then, a random sample of 1000 individual applications was selected and a sampling error of five per cent was identified. Of course, this selection method prioritizes efficiency over accuracy, which, we believe, is a necessary compromise when dealing with such a large number of filings. The alternative would be to go through each application manually.

\section{Table 1. Criteria used to classify PCT 2013-2015 applications into four categories}

\begin{tabular}{|c|c|}
\hline Individual & Name of an individual as the first applicant ${ }^{9}$ \\
\hline $\begin{array}{l}\text { Government, univer- } \\
\text { sity and research in- } \\
\text { stitute/center }\end{array}$ & 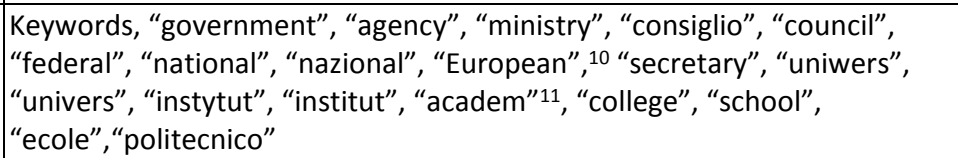 \\
\hline Company & $\begin{array}{l}\text { Name of a company, also with help of key words, "company”, “incorpo- } \\
\text { rated”, “limited”, “incorporée”, “limitée”, “corporation” and abbreviations, } \\
\text { Ltd., LLC., L.L.C., LC, L.C., Inc., Co., Corp., S.p.A., L.L.P., R.L.L.P., LLP, RLLP, 12 }\end{array}$ \\
\hline
\end{tabular}

\footnotetext{
${ }^{8} 87$ countries and 5 groups of countries, International Bureau of WIPO, European Patent Organization (EPO), African Regional Intellectual Property Organization (ARIPO), African Intellectual Property Organization (OAPI), Eurasian Patent Organization (EAPO).

${ }^{9}$ This group contained remaining PCT filings after removing company, government and academic applications. The group of individual applicants was manually scanned for errors.

${ }^{10}$ We tested the appropriateness of using keywords like "national" for "federal" for this category. In many cases, the names of private companies contained these two words, especially in the USA. We preselected the filings based on these key words but then we sorted them out manually and placed into the appropriate group. The word "European" applied mostly to the institutions of the European Union. The word "secretary" applied to various public offices, including the administration of the US Secretary of State. The word "state", however, was found to be a poor indicator of government affiliation.

11 "Univers" was used to capture foreign words for a university like "université", "universidad", "universität", etc.; "institut" - "institute", "instituto"; "academ" - "academy", "academic", "academia", "academie".

${ }^{12}$ Companies Incorporated, General Corporate Services, Inc., Corporation, LLC, and Fictitious Name Requirements, https://companiesinc.com/start-a-business/corporation/corporation-llc-fictitious-name-requirements Accessed 9 March, 2018.
} 


\begin{tabular}{|c|l|}
\hline Individual & \multicolumn{1}{|c|}{ Name of an individual as the first applicant ${ }^{9}$} \\
\hline & $\begin{array}{l}\text { GmbH, AG, UG, KGaA, }{ }^{13} \text { Ltée, }^{14} \text { S.A.R.F., SARF } \\
\text { tities in } 50 \text { countries }\end{array}{ }^{16}$ \\
\hline
\end{tabular}

Source: own authorship.

\section{RESULTS AND DISCUSSION}

\section{Different Categories of PCT Filings and GDP}

We looked at the relationship between the three categories of PCT applications and GDP per capita in 92 countries for 2013-2015. The GDP data come from the World Bank and the International Monetary Fund. We used the GDP per capita for 2015 and 2016 (in current US\$, accessed April 2018) from the World Bank. ${ }^{17}$ The GDP data for 2017 (in current US\$, accessed May 2018) are from the IMF. ${ }^{18}$ We use a two-year time lag for the GDP data based on the assumption that the effects of the inventive activity on GDP should take time to materialize. We took a two year period as a somewhat arbitrary measure and because PCT applications are published and become public no later than 18 months since the filing.

Table 2 presents the results of the Tukey post-hoc test. ${ }^{19}$ The test shows differences in the group means. In 2013, individual patent applications "contributed" on average less than 5,027 US\$ per capita to GDP than company applications and less than 3,595 US\$ than government and university applications. In 2014, the indirect contribution of individual PCT applications vis-à-vis company and government/university on average was less than 6,234 US\$ and less than 5,458 US\$ respectively. All of these differences are statistically significant at the 0.01 level, supporting the assumption that individual invention in emerging markets and developing economies, which have lower GDP than developed countries, has a lower probability of transitioning into the innovation and commercialization stage. This transition is conditioned by a number of meso and macro prerequisites, which are frequently lacking in those countries.

\footnotetext{
${ }^{13}$ Deditoor, Kapitalgesellschaft - Was ist eine Kapitalgesellschaft? https://debitoor.de/lexikon/kapitalgesellschaft. Accessed 8 March, 2018.

14 "Ltée" is the equivalent of "Ltd." in French. See at Government of Canada, Bilingual Names, https://www.ic.gc.ca/eic/site/cd-dgc.nsf/eng/cs04538.html. Accessed 8 March, 2018.

${ }^{15}$ Desroches Mongeo Aavocats, Quelle Est La Différence Entre Une Compagnie " Inc 》 Ou " Ltée ", https://desrochesmongeonavocats.com/quelle-est-la-difference-entre-une-compagnie-inc-ou-Itee/. Accessed 8 March, 2018.

${ }^{16}$ We used the article "The List of Business Entities" from Wikipedia to identify the abbreviations for for-profit business entities in 50 jurisdictions in addition to the abbreviations listed in Table 1 from the US, Germany and Canada. See at https://en.wikipedia.org/wiki/List_of_business_entities\#Spain. Accessed 10 March, 2018.

${ }_{17}$ Please see details at the World Bank Data, https://data.worldbank.org/indicator/NY.GDP.PCAP.CD?end=2016\&start=2015. Accessed in April 2018.

18 Please see details at the IMF, http://www.imf.org/external/datamapper/NGDPDPC@WEO/OEMDC/ADVEC/WEOWORLD. Accessed in May, 2018.

${ }^{19}$ This test is suitable because "the type of patent applicant" is a categorical variable.
} 
Table 2. Results of Tukey post-hoc test for three categories of PCT applications and GDP per capita (current US\$, 2018) for 92 countries, ${ }^{20}$ 2013-2015

\begin{tabular}{|c|c|c|c|c|}
\hline $\mathbf{X}$ & $\mathbf{Y}$ & $\mathbf{2 0 1 3}$ & $\mathbf{2 0 1 4}$ & $\mathbf{2 0 1 5}$ \\
\hline \multirow{2}{*}{ Category of PCT applicant } & $\begin{array}{c}\text { Mean Difference } \\
\text { GDP per capita, } \\
2015(\mathrm{X}-\mathrm{Y})\end{array}$ & $\begin{array}{c}\text { Mean Difference } \\
\text { GDP per capita } \\
2016(\mathrm{X}-\mathrm{Y})\end{array}$ & $\begin{array}{c}\text { Mean Difference } \\
\text { GDP per capita } \\
2017(\mathrm{X}-\mathrm{Y})\end{array}$ \\
\hline \multirow{2}{*}{ Individual } & Company & $-5,072.29^{*}$ & $-6,234.15^{*}$ & $-5,489.11^{*}$ \\
\cline { 2 - 5 } Company & $\begin{array}{c}\text { Government/uni- } \\
\text { versity }\end{array}$ & $-3,595.28^{*}$ & $-5,458.29^{*}$ & $-4,845.84^{*}$ \\
\cline { 2 - 5 } & $\begin{array}{c}\text { Government/uni- } \\
\text { versity }\end{array}$ & $5,072.29^{*}$ & $6,234.15^{*}$ & $5,489.11^{*}$ \\
\hline $\begin{array}{c}\text { Government/uni- } \\
\text { versity }\end{array}$ & Individual & $3,477.01^{*}$ & $775.86^{*}$ & $643.27^{*}$ \\
\cline { 2 - 5 } & Company & $-1,477.01^{*}$ & $-775.86^{*}$ & $-643.27^{*}$ \\
\hline
\end{tabular}

* The mean difference is significant at the 0.01 level.

Source: own authorship based on data from WIPO Statistics Database, the World Bank and the IMF.

\section{Micro, Meso and Macro Prerequisites}

Individual patenting has a smaller probability of being commercially realized in developing countries due to a number of lacking meso and macro-level prerequisites. The model of macro, meso and micro conditions for the commercial realization of individual inventions is presented in Figure 1 below. At the macro level, the availability of venture capital is a critical condition to turn invention into innovation and then diffuse it. The necessary entrepreneurial infrastructure that connects those who possess financial resources with those who generate ideas is, indeed, a logical prerequisite for the economic realization of those ideas. The inefficiencies of the local venture capital infrastructure in developing economies or emerging markets hinder the ability of isolated inventors and small businesses to commercially realize their inventions (Gianella \& Tompson, 2007). Another important prerequisite of innovation is the overall conduciveness of the business environment. Such factors as laws protecting property rights and intellectual property (IP) rights in particular, efficient tax system, absence of corruption and mechanisms of contract enforcement create conducive environment for innovation and commercialization of inventions. And when these institutional prerequisites are lacking, then innovation and commercial realization of invention becomes a risky undertaking especially for individual inventors and small businesses, including start-ups initiated by individual inventors to promote their inventions. It has been ascertained that SMEs (vis-à-vis larger business) in institutionally-challenged countries are less inclined to pursue innovation, due to high risks associated with deficits in the IP rights protection system or high levels of corruption (Zhu et al., 2011). Government support can also take form of government programs, subsidies and various kinds of initiatives, including financing schemes targeting specific industries or types of innovative firms such as SMEs or exporting businesses.

\footnotetext{
2087 countries and 5 groups of countries, International Bureau of WIPO, European Patent Organization (EPO), African Regional Intellectual Property Organization (ARIPO), African Intellectual Property Organization (OAPI), Eurasian Patent Organization (EAPO).
} 
To sum up, because of the lack of commercialization potential of individual patent applications due to lacking macro-level prerequisites in developing economies or emerging markets, their economic effects on GDP might be limited. The macro-level conditions for successful realization of invention are summarized in Figure 1.

At the meso level (also see Figure 1), industrial clusters or geographical concentrations of interconnected companies and institutions in a particular field or industry (Porter, 1998) are important enhancers of the innovation activity. Technological clusters like Silicon Valley facilitate learning, exchange of information, economies of scale in R\&D via high concentrations of capable suppliers and human capital, partnerships, alliances and other forms of synergetic activities boosted by face-to-face interactions. The availability to venture capital infrastructure in places like Silicon Valley helps aspiring inventors become entrepreneurs and realize their ideas themselves. There is also a market for ideas with big players like Google licensing or buying promising technology. The ability to tap into this regional network that offers various resources increases the probability of successful realization of inventions, be it individual inventors or large corporations. Another important meso-level factor is the ability to join a networking group, benefit from mentorship or work in cooperation with other inventors (Kim et al., 2016). This ability is somewhat related to the concept of industrial clusters, but does not have to be necessarily realized in a regional hub or within one industry. These networking structures take forms of professional associations, clubs, social groups, even Internet communities and, thus, can be inter-industry or have national membership, the main condition being that they enable or empower aspiring inventors to become entrepreneurs.

An act of entrepreneurship or the process of transformation of ideas into tangible outputs like products or services and then their commercialization normally takes place in some form of an organizational setting. An act of individual entrepreneurship is, of course, possible and there are precedents like Hewlett Packard or Apple, which are the example of highly successful businesses that started in a garage. However, sooner or later an act of a lonely entrepreneur becomes more socially (she is joint by other people) and institutionally embedded. This is, of course, provided that our inventor is an entrepreneur or wants to realize her idea with the help of an entrepreneur. If not, then her options are limited to selling or licensing her technology. Also, at the micro level much depends on the individual characteristics of an inventor, her entrepreneurial potential, which could be tied to her socio-economic status, education and experience. Plus, the nature of technology can determine its success as well (please see Figure 1 below for the summary of micro-level conditions).

Of course, based on our data, we cannot reach the conclusion that individual patenting leads to economic backwardness. The relationship might be working in the other direction, more economically advanced countries have a better venture capital infrastructure, better institutional environment or simply more internationally-oriented firms engaged in innovation. Regardless of the direction of the relationship, the link is there and can be visualized by the pattern that we called "quadrants of invention". 


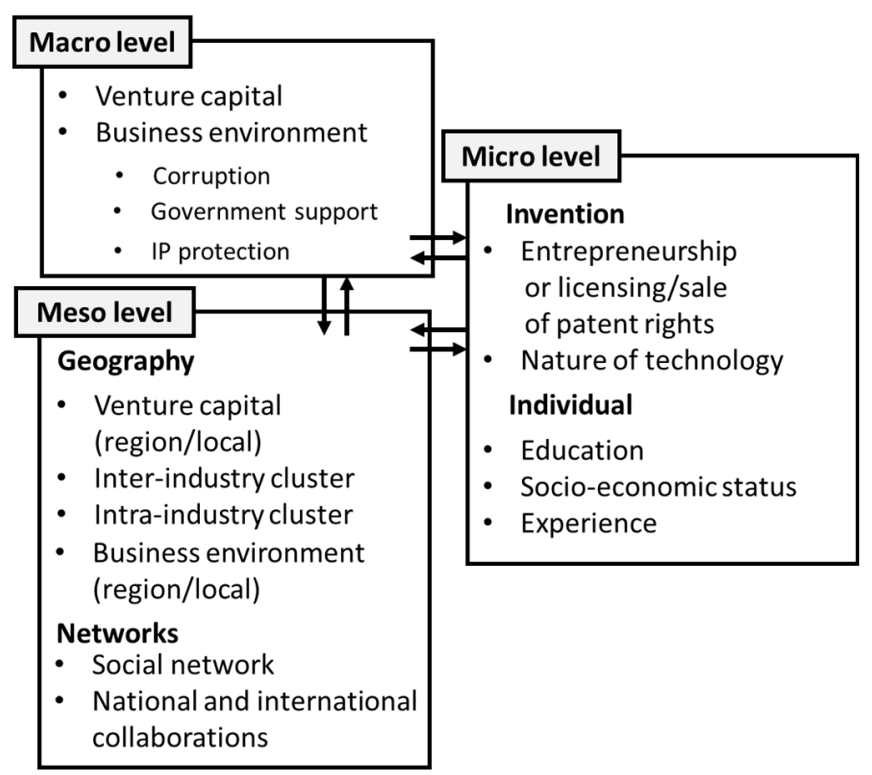

Figure 1. Factors affecting commercial potential of individual PCT applications Source: own authorship.

\section{Quadrants of Invention}

The association between GDP per capita and the percentage of individual applications from the total number of applications in each country for 36 countries and two groups of countries $^{21}$ is plotted in Figure 2 (PCT data for 2013), Figure 3 (PCT data for 2014) and Figure 4 (PCT data for 2015). ${ }^{22}$ The countries are divided into three categories or quadrants, based on GDP per capita and intensity of individual invention. The patterns are clear, plausible and consistent throughout the three years. The way data are distributed cannot be coincidental and demonstrates that countries with lower GDP per capita tend to produce more individual patent applications. This observation embodies the fundamental divide, grounded in the writings of Schumpeter, between invention and innovation. Innovation presupposes a practical and economically exploitable realization of an idea expressed in a patent application by a company (including an entrepreneur-driven start-up) or, to a lesser extent, as we ascertained above, a government agency or a research institute or university, and should lead to higher levels of productivity and economic development. Plus, in developing economies and emerging markets certain macro and meso conditions that help turn invention into innovation are not fulfilled.

Quadrant 1 in the left top corner is occupied by countries that share high levels of GDP per capita and low levels of individual patent applications (under 20 percent). In 2013, they

\footnotetext{
${ }^{21}$ The two groups of countries are the International Bureau of WIPO with the "IB" code assigned to a patent application and the European Patent Organization (EPO) members - with the "EP" code.

22 After summarizing patent application data for different categories of PCT applications (for 92 countries and groups of countries), the list was then shortened to 38 units, with a significant number of patent applications in at least one category $(n>50)$.
} 
include Switzerland, Norway, US, Australia, Singapore, Denmark, Sweden and IB. "IB" stands for International Bureau of WIPO. ${ }^{23}$ In 2014, the group contains Switzerland, Norway, US, Denmark, Sweden, Singapore, IB, Australia, Netherlands, Austria, Finland, Canada and Great Britain. In 2015, - Switzerland, Norway, US, Singapore, Denmark, Australia, Sweden and IB. This outcome is expected - more institutionally developed countries are in a better capacity to generate income from invention.

The lower-left quadrant - Quadrant 2 - is occupied by countries that have less than 50 per cent of individual applications from the total. In 2013, the list includes (along the $\mathrm{X}$ axis) Japan, EP ${ }^{24}$, Finland, France, Great Britain, China, Malaysia, South Korea, Israel, Austria, Canada, Portugal, Germany, New Zealand, Czech Republic, Poland, India, Italy, Slovenia, Spain, Hungary, Brazil and Romania. It is interesting to note that Malaysia, China, Brazil and India, emerging markets due to high economic growth rates, are grouped together with the new post-2004 EU members Poland, Hungary, Czech Republic and Slovenia. In 2014, - Japan, EP, France, Malaysia, South Korea, China, Israel, Czech Republic, Poland, India, Italy, Portugal, Slovenia, Spain, Brazil, Hungary and Turkey. In 2015, - Japan, EP, Finland, France, Netherlands, Malaysia, Great Britain, Germany, Slovenia, China, South Korea, Canada, Israel, India, Austria, New Zealand, Poland, Italy, Czech Republic, Portugal, Romania, Spain, Turkey, Brazil, Hungary.

Quadrant 3 has just a few occupants. The countries in the third quadrant have high levels of individual patenting (percentage of individual PCT applications is higher than by company and government/university applications combined) and comparatively low levels of economic development (GDP per capita is roughly at the 20,000 US\$ or below). In 2013, the group contains Russia, Turkey, Mexico, South Africa, Greece and Ukraine. In 2014, - Romania, Russia, Mexico, South Africa, Ukraine and Greece. In 2015, - Russia, South Africa, Mexico, Ukraine and Greece.

The fact that there are no countries in the upper-right quadrant, confirms the incompatibility of high levels of individual patent activity and high levels of economic development. This supports assumptions in Schumpeter about the significance of innovation, in that it is able to develop and exploit economically inventions undertaken by the private sector. Innovation is essentially an act of entrepreneurship. It implies practically-oriented conceptualization, development, implementation of an invention, be it new product, process, etc., with the aim of profit maximization. Profit maximization is an ultimate motivation of a private enterprise. Thus, the type of patent application or whether it is an individual inventor or a commercially-oriented enterprise seems to be an important factor in achieving higher levels of economic development. This relationship is not direct, however. There are specific conditions at the micro (individual characteristics of an inventor and her readiness to commercially realize an invention herself); meso (industrial clusters of innovative activity and embeddedness in social networks); and macro level (business-friendly institutions and venture capital infrastructure). If these conditions are met (not necessarily all of them simultaneously, but at least some serendipitous combination), then invention

\footnotetext{
${ }^{23}$ GDP per capita for "IB" applications were calculated as the average for the highest GDP per capita among the WIPO members (Monaco) and the lowest (Burundi).

24 "EP" stands for the patent application filed with the European Patent Organization (EPO). EP GDP per capita here was calculated as an average for EPO members.
} 


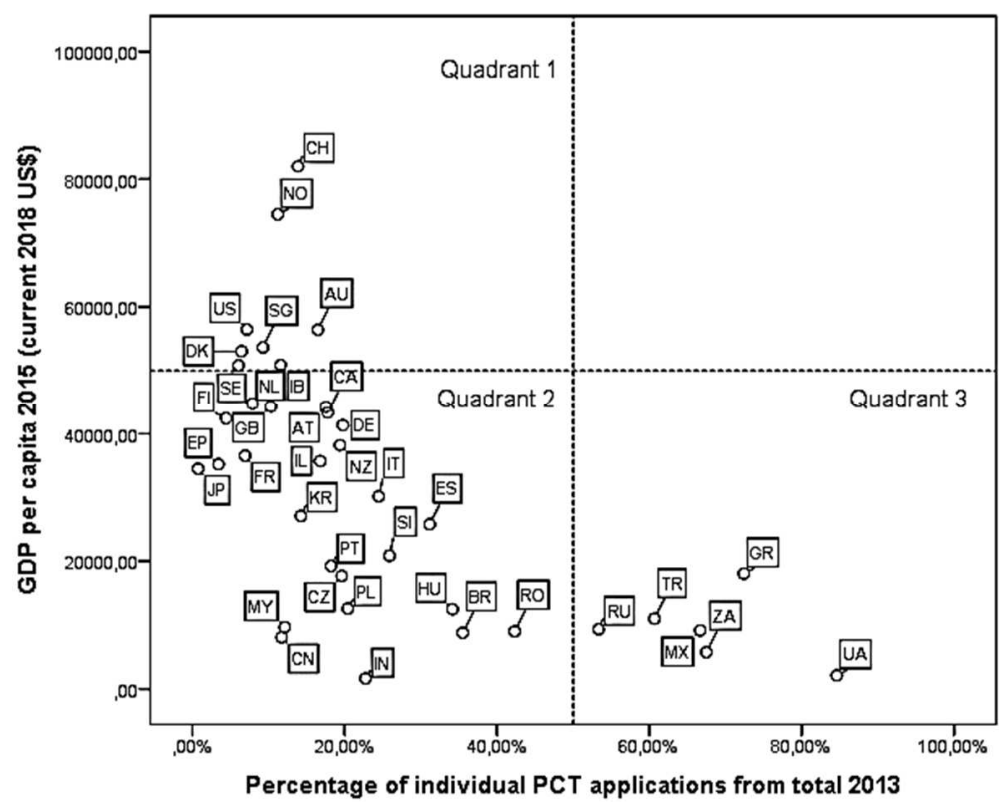

Figure 2. Relationship between GDP per capita 2015 (current US\$, 2018) and percentage of individual PCT patent applications (2013)

Source: own authorship based on data from WIPO Statistics Database and the World Bank.

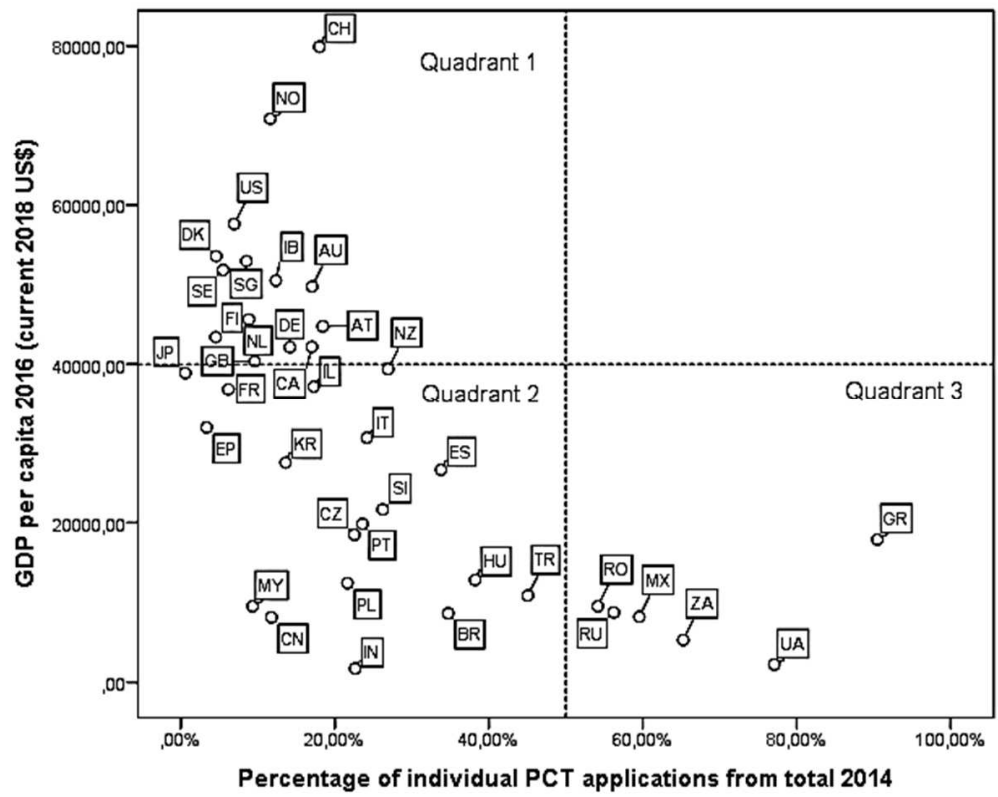

Figure 3. Relationship between GDP per capita 2016 (current US\$, 2018) and percentage of individual PCT patent applications (2014)

Source: own authorship based on data from WIPO Statistics Database and the World Bank. 


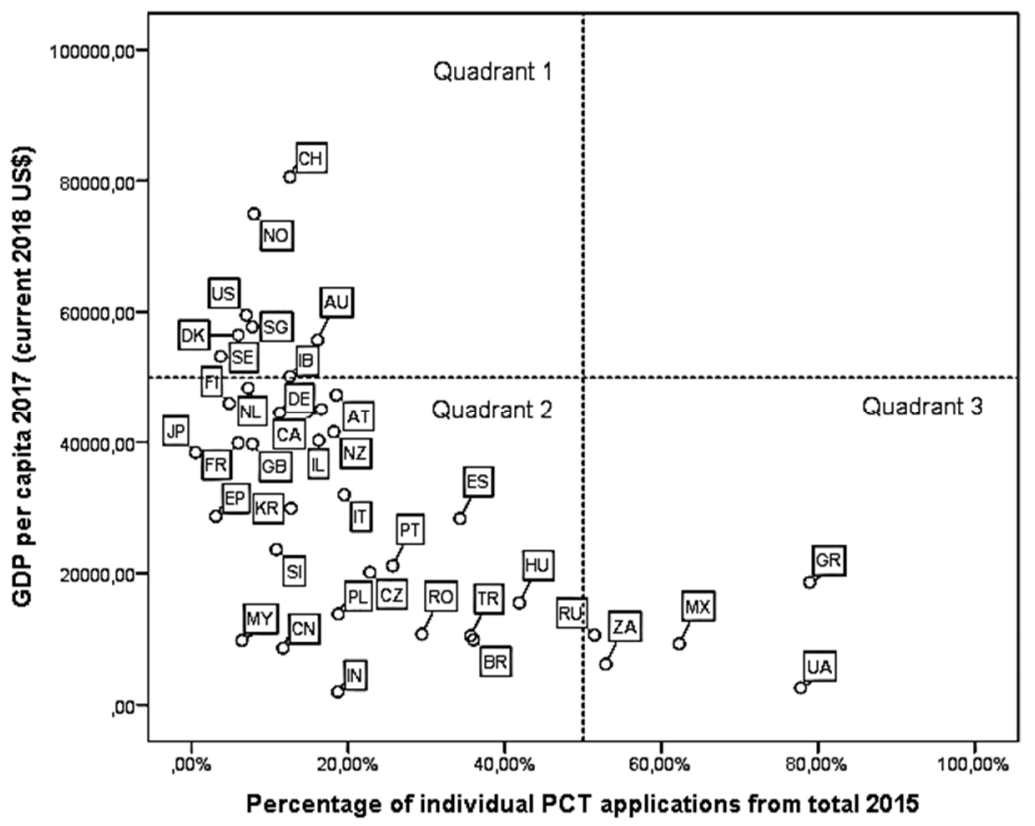

Figure 4. Relationship between GDP per capita 2017 (current US\$, 2018) and percentage of individual PCT patent applications (2015)

Source: own authorship based on data from WIPO Statistics Database and the IMF.

can turn into innovation and bring economic results. In the case of the countries in the third quadrant, namely Russia, South Africa, Mexico, Greece, and Ukraine, this serendipitous combination of prerequisites is not materializing due to the nature of patenting (high percentage of individual applications and, hence, lack of corporate/government/academic backing) and due to the inability to meet macro and meso conditions.

\section{CONCLUSIONS}

The paper explored the sample of roughly 600,000 PCT applications for three years (2013-2015). We introduce the concept of "quadrants of invention" reflecting the relationship between the percentage of individual PCT applications and GDP per capita. Quadrants of invention present a clear picture of countries being divided into three separate groups. Quadrant 3 countries produce more individual patent applications as a percentage of the total number of filings.

The results of the Tukey post-hoc test show that there are variations in the group "contributions" to GDP, with company applications "contributing" the most. Our results indicate a link between the three different categories of PCT applications and GDP, but the relationship is not direct. The process of transitioning from invention into innovation and commercialization depends on a number of conditions. The specific factors playing a role in the economic realization of invention are institutions and availability of venture capital 
(macro), industrial clusters and embeddedness in social network (meso), and, finally, individual potential to commercially realize an invention (micro). Who files a patent application is important for its future realization. Economic progress is driven by corporate or other forms of organizational inventors because these inventions are backed up by organizational resources and, thus, have a better chance of transitioning into innovation and then being diffused. This argument takes us back to the insights provided by Schumpeter on the nature of the innovation process. Invention, an act of creativity, according to Schumpeter, should be separated conceptually from the process of innovation, as innovation is associated closely with an act of entrepreneurship or the economic realization of inventive ideas and designs. This act of entrepreneurship, i.e. the ability to "get things done" or realize patents economically, is what differentiates organizationally-based or backed innovation (either a start-up being able to find venture capital or a multinational company, or even a government-funded research institute) from lonely invention.

The three quadrants of invention are the result of the association between GDP per capita and the percentage of international patent applications by individuals. These quadrants demonstrate that individual internationally-oriented invention is more characteristic of developing economies or emerging markets like Russia or Mexico, whilst developed countries with higher levels of economic development, measured by GDP per capita, do not tend to produce similar proportions of individual patent applications. Thus, when comparting inventive output of countries, the percentage of individual patenting could serve as an important indicator of the future economic utility of these inventions. Who files an application matters. Using the total number of applications that a country produces as an indicator does not capture the differences in their commercialization potential.

The limitation of this project is its explorative and descriptive nature. Future research can look into the reasons behind high levels of individual patenting in such countries as Russia, Ukraine or Mexico. There is a number of possible explanations. First, since PCT patents are essentially international patents then high percentage of individual patenting might signal something similar to brain drain - individuals seeking market opportunities for their ideas abroad - with one difference that they do not physically leave their country. Their inventive effort is internationally-oriented because the opportunities to commercialize their ideas at home are limited due to deficient business infrastructure, corruption or draconian regulations. However, Ervits \& Zmuda (2018), after analyzing cross-national PCT patenting, conclude that poor institutions do not necessarily drive small businesses to file an international patent application. Poor institutions translate into fewer filings by small businesses. Griliches proposed that low real wages spur individual patenting in developing economies because patenting offers income alternatives (1990), for example, in the form of royalties from licensing. This assumption can be empirically tested.

To sum up, for the first time we demonstrate that high levels of individual patenting are more characteristic of developing rather than developed economies. The fact that individual patent applications originate in developing economies or emerging markets implies lower chances of their commercial realization due to the lack of macro and meso prerequisites. The paper suggests using the percentage of individual patent applications vis-à-vis other categories of inventor filings as an important indicator of national innovative capacity. An entrepreneurial effort exercised in some form of organization (preferably a profit-driven organization) is what differentiates innovation from an act of invention. 
Seen through this light, high levels of individual patenting serve as an indicator of potentially unutilized innovative capacity rather than innovative output. In other words, the cross-country levels of individual patenting create a more realistic picture when utilized as a separate assessment criterion of innovative capacity. This conclusion has policy implications with regard to specific measures on the macro and meso levels that can help commercially realize the potential of individual inventions, for instance, enhancement of industrial clusters or overall improvement of institutional conditions. The transformation of invention into innovation does not happen automatically and requires a conscious and concentrated entrepreneurial effort that can, however, be assisted by appropriate business and institutional infrastructure.

\section{REFERENCES}

Aitken, B., \& Harrison, A. (1994). Do Domestic Firms Benefit from Foreign Direct Investment? Evidence from Panel Data. Policy Research Working Paper 1248, The World Bank Policy Research Department, Trade Policy Division.

Almeida, P., Hohberger, J., \& Parada, P. (2011). Individual Scientific Collaborations and Firm-level Innovation. Industrial and Corporate Change, 20(6), 1571-1599.

Amesse, F., Desranleau, C., Etemad, H., Fortier, Y., \& Seguin-Dulude, L. (1991). The Individual Inventor and the Role of Entrepreneurship: A Survey of the Canadian Evidence. Research Policy, 20, 13-27.

Bradford University School of Management (2009). Mapping Organizational Capabilities for Innovation and Competitiveness: Research Performance and Patenting in Small Open Economies. BUSM, Manchester Institute of Innovation and Research, Manchester Business School, and University College Cork, Department of Economics.

Braunerhjelm, P., \& Svensson, R. (2010). The Inventor's Role: Was Schumpeter Right? Journal of Evolutionary Economics, 20(3), 413-444.

Cantwell, J., \& Janne, O. (1999). Technological Globalisation and Innovative Centres: The Role of Corporate Technological Leadership and Locational Hierarchy. Research Policy, 28(2/3), 119-144.

Cantwell, J., \& Piscitello, L. (2005). Recent Location of Foreign-Owned Research and Development Activities by Large Multinational Corporations in the European Regions: The Role of Spillovers and Externalities. Regional Studies, 39(1), 1-16.

Castellacci, F. (2007). Technological Regimes and Sectoral Differences in Productivity Growth. Industrial Corporate Change, 16(6), 1105-163.

Comanor, W.S., \& Scherer, F. (1969). Patent Statistics as a Measure of Technical Change. Journal of Political Economy, 77(3), 392-398.

Czarnitzki, D., Hussinger, K., \& Schneider, C. (2011). Commercializing Academic Research: The Quality of Faculty Patenting. Industrial and Corporate Change, 20(5), 1403-1437.

Dahlin, K., Taylor, M.R., \& Fichman, M. (2004). Today's Edisons or Weekend Hobbyists: Technical Merit and Success of Inventions by Independent Inventors. Research Policy, 33, 1167-1183.

Dosi, G., Marsili, O., Orsenigo, L., \& Salvatore, R. (1995). Learning, Market Selection and the Evolution of Industrial Structures. In G. Dosi (Ed.), Innovation, Organization and Economic Dynamics (pp. 433-458). Edward Elgar.

Dosi, G., \& Nelson, R. (2013). The Evolution of Technologies: An Assessment of the State-of-the-art. Eurasian Business Review, 3(1), 3-46.

Ervits, I., \& Zmuda, M. (2018). A Cross-country Comparison of the Effects of Institutions on Internationally Oriented Innovation. Journal of International Entrepreneurship, 16, 486-503. 
Fabrizio, K.R. (2007). University Patenting and the Pace of Industrial Innovation. Industrial and Corporate Change, 16(4), 505-534.

Fagerberg, J. (2013). Innovation - A New Guide. TIK Working Papers on Innovation Studies, No. 20131119, Centre for Technology, Innovation and Culture.

Fontana, R., Nuvolari, A., Shimizu, H., \& Vezzulli, A. (2012). Schumpeterian Patterns of Innovation and the Sources of Breakthrough Inventions: Evidence from a Data-set of R\&D Awards. Journal of Evolutionary Economics, 22(4), 785-810.

Frank, M. (1998). Schumpeter on Entrepreneurs and Innovation: A Reappraisal. Journal of the History of Economic Thought, 20(4), 505-516.

Frost, T.S. (2001). The Geographic Sources of Foreign Subsidiaries' Innovations. Strategic Management Journal, 22, 101-123.

Granstrand, O., \& Alaenge, S. (1995). The Evolution of Corporate Entrepreneurship in Swedish Industry - Was Schumpeter Wrong? Journal of Evolutionary Economics, 5(2), 133-156.

Gianella, C., \& Tompson, W. (2007). Stimulating Innovation in Russia: The role of Institutions and Policies. OECD Papers, 7(1), 1-47.

Griliches, Z. (1990). Patent Statistics as Economic Indicators: A Survey. Journal of Economic Literature, 28(4), 1661-1707.

Griliches, Z., \& Schmookler, J. (1963). Inventing and Maximizing. American Economic Review, 53(4), 725-29.

Hagedoorn, J. (1996). Innovation and Entrepreneurship: Schumpeter Revisited. Industrial and Corporate Change, 5(3), 883-896.

Jaffe, A.B., \& Trajtenberg, M. (2002). Patents, Citations, and Innovations: A Window on the Knowledge Economy. MIT Press.

Jewkes, J., Sawers, D., \& Stillerman, R. (1958). The Sources of Invention. Macmillan.

Khan, B.Z., \& Sokoloff, K.L. (2004). Institutions and Democratic Invention in $19^{\text {th }}$-Century America: Evidence from "Great Inventors," 1790-1930. American Economic Review, Papers and Proceedings, 94(2), 395-401.

Kim, P.H., Wennberg, K., \& Croidieu, G. (2016). Untapped Riches of Meso-Level Applications in Multilevel Entrepreneurship Mechanisms. Academy of Management Perspectives, 30(3), 273-291.

King, J.L., Gurbaxani, V., Kraemer, K. L., McFarlan, F. W., Raman, K. S., \& Yap, C. S. (1994). Institutional Factors in Information Technology Innovation. Information Systems Research, 5(2), 139-169.

Marsili, O., \& Verspagen, B. (2002). Technology and the Dynamics of Industrial Structures: An Empirical Mapping of Dutch Manufacturing. Industrial and Corporate Change, 11(4), 791-815.

Malebra, F., \& Orsenigo, L. (1995). Schumpeterian Patterns of Innovation. Cambridge Journal of Economics, 19(1), 47-65.

Malerba, F., \& Orsenigo, L. (1997). Technological Regimes and Sectoral Patterns of Innovative Activities. Industrial Corporate and Change, 6(1), 83-117.

Mazzucato, M. (2015). From Market Fixing to Market-creating: A New Framework for Economic Policy. ISIGrowth Working Paper, 2.

Mazzucato, M. (2018). Mission-oriented Innovation Policies: Challenges and Opportunities. Industrial Corporate and Change, 27(5), 803-815.

Mowery, D.C., \& Sampat, B. N. (2001). University Patents and Patent Policy Debates in the USA, 1925-1980. Industrial \& Corporate Change, 10(3), 781-814.

Mueller, D.C. (1966). Patents, Research and Development, and the Measurement of Inventive Activity. Journal of Industrial Economics, 15(1), 26-37. 
Organization for Economic Co-operation and Development and Statistical Office of the European Communities (1996). Oslo manual: Guidelines for Collecting and Interpreting Innovation Data. OECD Publishing.

Organization for Economic Co-operation and Development and Statistical Office of the European Communities (2005). Oslo manual: Guidelines for Collecting and Interpreting Innovation Data. 3rd Edition. OECD Publishing.

Pavitt, K., \& Soete, L. (1980). Innovative Activities and export shares: Some comparisons between industries and countries. In K. Pavitt (Ed.), Technical Innovation and British Economic Performance (pp. 38-66). Macmillan.

Perri, A., Scalera, V.G., \& Mudambi, R. (2017). What are the Most Promising Conduits for Foreign Knowledge Inflows? Innovation Networks in the Chinese Pharmaceutical Industry. Industrial \& Corporate Change, 26(2), 333-355.

Pinchot, G. (1985). Intrapreneuring: Why You Don't Have to Leave the Corporation to Become an Entrepreneur. Joanna Cotler Books.

Porter, M.E. (1998). Clusters and The New Economics of Competition, Harvard Business Review, 76(6), 77-90.

Romer, P. (1986). Increasing Returns and Long-run Growth. Journal of Political Economy, 94(5), 10021037.

Romer, P. (1990). Endogenous Technological Change. Journal of Political Economy, 98(5), 71-102.

Ruttan V.W. (1959). Usher and Schumpeter on Invention, Innovation, and Technological Change. Quarterly Journal of Economics, 73(4), 596-606.

Scherer, F M. (1965). Corporate Inventive Output, Profits, and Growth. Journal of Political Economy, 73(3), 290-297.

Scherer, F.M. (1992). Competing for Comparative Advantage through Technological Innovation. Business and the Contemporary World, Summer, 30-39.

Schmookler, J. (1966). Invention and Economic Growth. Harvard University Press.

Schmookler, J., \& Brownlee, O. (1962). Determinants of Inventive Activity. American Economic Review, 52(2), 165-176.

Schumpeter, J. (1911). The Theory of Economic Development. Harvard University Press.

Schumpeter, J. (1939). Business Cycles. A Theoretical, Historical and Statistical Analysis of the Capitalist Process. McGraw-Hill Book Company.

Schumpeter, J. (1942). Capitalism, Socialism and Democracy. Taylor \& Francis e-Library.

Schumpeter, J. (1947). The Creative Response in Economic History. The Journal of Economic History, $7(2), 149-159$.

Singh, J., \& Fleming, L. (2010). Lone Inventors as Sources of Breakthroughs: Myth or Reality? Management Science, 56(1), 41-56.

Sood, J., \& DuBois, F. (1995). The Use of Patent Statistics to Measure and Predict International Competitiveness. International Trade Journal, 9(3), 363-379.

Trajtenberg, M. (2002). Innovation in Israel 1968-1997: A Comprehensive Analysis Using Patent Data. In A. B. Jaffe and Trajtenberg, M. (Eds.) Patents, Citations, and Innovations: A Window on the Knowledge Economy 337-375. MIT Press.

Weick, C. W., \& Eakin, C. F. (2005). Independent Inventors and Innovation: An Empirical Study. The International Journal of Entrepreneurship and Innovation, 6(1), 5-15. 
World Intellectual Property Organization (2015a). Protecting your Inventions Abroad: Frequently Asked Questions about the Patent Cooperation Treaty. WIPO. http://www.wipo.int/pct/en/faqs/faqs.html\#note1. Accessed 15 April 2015.

World Intellectual Property Organization (2015b). The PCT Applicant's Guide. WIPO. http://www.wipo.int/pct/en/appguide/. Accessed 15 April 2015.

World Intellectual Property Organization (2015c). Glossary, WIPO. http://www.wipo.int/ipstats/en/statistics/glossary.html. Accessed 15 April 2015.

World Intellectual Property Organization (2016). List of WIPO Standards. Handbook on Industrial Property Information and Documentation Standards - ST.3. WIPO. www.wipo.int/standards/en/pdf/03-03-01.pdf. Accessed 2 June 2016.

Zanfei, A. (2000). Transnational Firms and the Changing Organization of Innovative Activities. Cambridge Journal of Economics, 24, 515-542.

Zhu, Y., Wittmann, X., \& Peng, M. (2012). Institution-based Barriers to Innovation in SMEs in China. Asia Pacific Journal of Management, 29(4), 1131-1142.

\section{Author}

\section{Irina Ervits}

Irina Ervits currently works at the International Business Department at Cologne Business School. Her research interests are in the areas of Innovation Management, including work with patent statistics, Institutional Economics and International Economics with a focus on emerging markets. One of her recent publication is 'Geography of Corporate Innovation: Internationalization of Innovative Activities by MNEs from Developed and Emerging Markets'.

Correspondence to: Irina Ervits, Department of International Business, CBS Cologne Business School, Hardefuststraße 1, 50677, Köln, Germany, e-mail: i.ervits@cbs.de ORCID (i) http://orcid.org/0000-0002-4729-9498

\section{Acknowledgements and Financial Disclosure}

The author would like to thank the anonymous reviewers for their useful comments.

\section{Copyright and License}

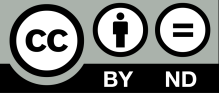

Published by the Centre for Strategic and International Entrepreneurship - Krakow, Poland
This article is published under the terms of the Creative Commons

Attribution - NoDerivs (CC BY-ND 4.0) License http://creativecommons.org/licenses/by-nd/4.0/

The journal is co-financed in the years $2019-2020$ by the Ministry of Science and Higher Education of the Republic of Poland in the framework of ministerial programme "Support for Scientific Journals" (WCN) on the basis of contract no. 238/WCN/2019/1 concluded on 15 August 2019. 
